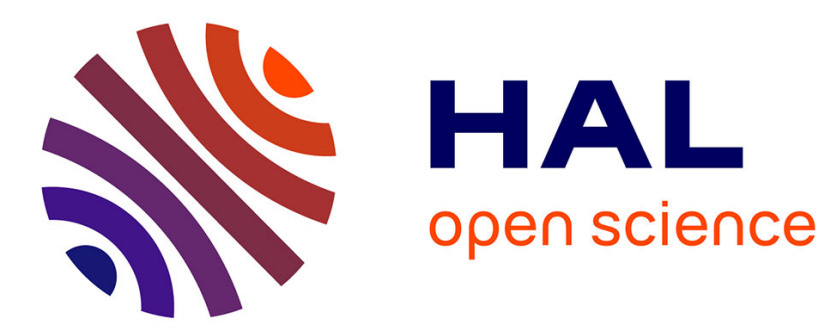

\title{
Environmental and Linguistic Typology of Whistled Languages
}

Julien Meyer

\section{To cite this version:}

Julien Meyer. Environmental and Linguistic Typology of Whistled Languages. Annual Review of Linguistics, 2021, 7 (1), pp.493-510. 10.1146/annurev-linguistics-011619-030444 . hal-03058925

\section{HAL Id: hal-03058925 \\ https://hal.science/hal-03058925}

Submitted on 5 Jan 2022

HAL is a multi-disciplinary open access archive for the deposit and dissemination of scientific research documents, whether they are published or not. The documents may come from teaching and research institutions in France or abroad, or from public or private research centers.
L'archive ouverte pluridisciplinaire HAL, est destinée au dépôt et à la diffusion de documents scientifiques de niveau recherche, publiés ou non, émanant des établissements d'enseignement et de recherche français ou étrangers, des laboratoires publics ou privés. 
TITLE PAGE

TITLE: Environmental and linguistic typology of whistled languages

AUTHOR: Julien Meyer

AFFILIATION: Université Grenoble Alpes, CNRS, GIPSA-lab, F-38000 Grenoble, France

EMAIL: julien.meyer@gipsa-lab.fr 


\section{KEYWORDS:}

Whistled language, whistled speech, language diversity, telecommunication, typology, adaptation

\section{ABSTRACT}

Whistled forms of languages are distributed worldwide and survive only in some of the most remote villages on the planet. They are not limited to a given continent, language family or language structure, but they have been detected only sporadically by researchers and travelers, partly because they can be taken for non-linguistic phenomena such as simple signaling. Whistled speech consists in speaking while whistling to communicate at long distance. The result is a melody which imitates modal speech and that remains intelligible for the interlocutors. Here, a typology of this special and little known traditional natural type of speech is proposed, taking in consideration socio-environmental and linguistic aspects. The amazing potential of this phenomenon to provide an alternative point of view into language diversity and speech offers a unique occasion to revisit human language with original insights embracing the adaptive flexibility that characterizes speech production and perception. 


\section{Introduction}

This review addresses a fascinating and little-known language practice based on whistling which represent one of the multiple modes of expression for some local languages. It profoundly modifies the phonetic system of the local speech: spoken speech is replaced by a simple modulated whistle, which carries all the information. Therefore, whistled speech is adapted both to the structure of each language and to the articulatory constraints of whistling. Several remote rural populations around the world use this special natural speech type (or speech mode) based on whistling to fulfill purely communicative purposes, mostly for long range dialogs. In these local communities, the speakers learn since childhood to copy any sentence of their language into a simpler whistled signal. This 'talking mode of whistling' - also called 'whistled speech' or 'whistled language' - is always based on a spoken language. People articulate words while whistling and thereby transform spoken utterances by simplifying them, syllable by syllable, into whistled melodies. It is not just simple signaling because the relationship between the whistled signal and the corresponding utterance in modal speech is based on acoustic similarity, combining abridgment and sound iconicity to highlight some salient features of the language that will be sufficient for the interlocutors to reconstruct cognitively the message. This speech type is conceptually different from the practice that consists in whistling a tune of a song by following the prosody of its sung lyrics that puts little pressure on the whistler for the transmission of the meaning of the lyrics.

A whistle is a simple narrow-band oscillation modulated in time, frequency and amplitude. One of the most striking aspects of this whistled transformation of words is that the whistled sentences remain highly intelligible to trained whistlers in a wide range of languages, despite the reduced acoustic channel to convey meaning (Meyer 2015). 
The functional role of this peculiar traditional language practice is to complement ordinary speech under certain circumstances (similarly to other speech types such as whispering, shouting or singing). It does not replace but instead complements modal speech, often under different circumstances. The persistence of whistled speech is always linked to a certain vitality of the traditional rural way of life. Strikingly both the existence and the survival of whistled languages are linked to specific traditional outdoor subsistence activities and facilitate the organization of everyday life when ordinary modal or shouted speech forms are inadequate. In summary, whistled speech was particularly found in association with the coordination of group activities such as hunting, fishing, food gathering, hill agriculture/harvesting, or caring for cattle. The association of whistled speech with certain traditional outdoor activities makes it very sensitive to behavioral changes due to the modernization of the countryside to the point that we diagnose the phenomenon as universally endangered. In the present review we will explore the diversity of languages that are whistled and how this phenomenon adapts to different languages and different socio environmental contexts.

\section{Whistled Language Diversity and Landscape Ecology}

\section{Geographic Locations and Language Families}

Whistled speech appears in a wide range of languages and language families on all inhabited continents of the planet (Figure 1 and Table 1). More than eighty languages with whistled speech have been reported in the world and around forty of them have been attested by studies or published recordings. However, whistled speech remains little known for several reasons: first, it was not always identified as a speech act because it can be mistaken for non-linguistic phenomena such as signaling. Next, this practice survives only in some of the most remote areas of the planet, and, for a great proportion, among populations speaking 
some of the less spoken and less documented languages of the world. Finally, it also quickly loses vitality with the modernization of rural life (see Text S3 in Supplemental Materials on whistled speech endangerment). However, recent fieldwork inquiries and large reviews of the literature on this subject have shown that languages with a whistled modality appear in such widely differing language families as Afro-Asiatic and Niger-Congo in Africa; Algonquian, Eskimo- Aleut and Oto-Manguean in North and Central America; Arawak, Jê and Tupian in South America; Altaic, Indo-European and Sino-Tibetan in Eurasia; and Torricelli, Trans-NewGuinea and Sepik in Oceania (Meyer 2015). This notable diversity extends considerably the range of former general studies on the subject dating back to 1976 and mentioning fewer than a dozen attested whistled languages (Busnel \& Classe 1976; Sebeok \& Umiker-Sebeok 1976). From the information that we gathered, many other languages are possibly involved in whistling, but additional fieldwork documentation would be necessary for verification. For example, several regions of the world-such as Southeast Africa, Asia beyond Southeast Asia and Southern China, Eastern Europe, the mountainous Western Americas and a large part of Oceania-have never been investigated for this phenomenon.

The notable diversity of this natural speech type shows that this practice is not limited to any particular linguistic structure or linguistic family. Instead, it suggests that all human languages can develop a whistled form if both ecological and social conditions require it (or 'socio-environmental' factors). As it was mentioned in the introduction, whistled transpositions of speech conform differently to some essential aspects of language structures, given that languages of the world use different sets of sound inventories to code their phonology and that whistling adapts to these sets in an original way, that is, differently as a function of the tonal/non tonal nature of the language. Here, the various tonal languages known to have evolved whistled speech show a large diversity of tonal systems, 
ranging from the complex contour tone structures of Asia, such as in Hmong, to the much simpler two-level tone systems of the Suruí of Rondônia (Brasil). Similarly, whistled speech stemming from non-tonal languages exists in a very large variety of vocalic and consonantal systems (Greek, Spanish, Tamazight, Turkish, Siberian Yupik, Wayãpi,...). We will develop these aspects more thoroughly when addressing the phonetic and phonological aspects of whistled languages.

\section{The special Relationship between Landscapes and Whistled Speech}

\section{A speech type found mostly associated to mountains and dense vegetation}

One of the most striking aspects of the worldwide distribution of whistled languages is that they are almost exclusively found in association with certain types of habitats: either mountainous topography (Figure S1) or highly vegetated landscapes (Figure S2). Our field inquiry not only confirmed the importance of mountainous areas but also highlighted a key association between whistled speech and dense tropical forests (Meyer 2015). According to the literature, there appears also to be an association between several African whistled languages and dense savannas [e.g., Gurunsi and Mooré in Burkina Faso (Eboué 1935; Junzo 1998)]. Whistled speech is also often found in several regions of the world where mountains and dense forests coexist 'such as the 'Sierra Mazateca' in Mexico (Mixtec, Mazatec and Chinantec languages), the Golden Triangle in Southeast Asia (Bai, Yi, Akha and Hmong) and the Sepik region of Papua New Guinea (Abu? and Wam Arapesh)). All of these aspects are summarized in the map in Figure 1.

To better understand what factors drive the special relationship of whistled forms of languages with specific ecological environments, it is necessary to further examine environmental and sociolinguistic aspects associated to the populations that engage in whistled speech. 


\section{Advantages of the bioacoustics properties of whistling}

Most notably, the ecological zones we mentioned have in common to create a strong demand for long-distance communication in rural settings because dense vegetation and rough topography isolate rapidly and frequently individuals and constrain spoken communications. Speakers living in such ecological milieux often find themselves scattered across great distances during outdoor activities unable to hear each other clearly via speaking or even shouting. The terrain configurations makes moving about difficult. Several areas remain quite isolated and can be reached only through long dirt tracks (or river boat trips in tropical forests). It can be very useful and safe in several daily situations to exchange information with all the communicative richness of a language, though. For example, to point out a danger or to give important news to someone located on the other side of a valley, of a river - or hidden by the forest. Shouting represents a universal adaptation of speech for such situations, but its range is limited in distance and shouted dialogs are necessarily short because the vocal folds get rapidly tired and damaged by efforts. Instead, the production of whistles does not cause the vocal folds to suffer as they are not used in a vibrating mode, but only to control the release of the air from the lungs. In shouting, to increase the range of modal speech or to overcome noise, individuals adjust their voices by raising amplitude levels in a quasi-subconscious way ("Lombard effect", Lombard (1911)); effort is intensified with the concomitant tendency to prolong syllables, to reduce the flow of speech and to increase the fundamental frequency (Meyer et al 2018). Whistled speech, which is typically produced at strong intensity levels (between 80 and $120 \mathrm{dBA}$ ) in a band of frequencies from 1 to $4 \mathrm{kHz}$ and at a general flow from $10 \%$ to $50 \%$ slower than modal speech (Moles 1970, Meyer 2005, Meyer \& Gautheron 2006) develops the same general bioacoustic strategy because speakers further increase these three fundamental parameters 
of speech (amplitude, frequency and duration) to improve speech detection and therefore ease speech decoding adapting more comfortably to the distance of communication and to the ambient noise. This happens without the noted disadvantages of shouting (i.e. reaching the biological limits of vocal folds)(Meyer 2008).

With whistled speech full sentences remain intelligible at distances ten times greater than that of shouted speech (Busnel \& Classe 1976, Meyer 2008). However, an important limitation hanging over any kind of long distance acoustic communication signals used outdoors in natural surroundings is that they are profoundly altered during propagation through the environment due to phenomena of absorption, reverberation, reflection, and selective filtering (Dabelsteen et al. 1993, Larsen et al. 2018). Such environmental constraints induce acoustic changes that may interfere with the transmission of the information conveyed between the emitter and the receiver, in particular because amplitude and frequency modulations as well as certain frequencies may be strongly decayed or blurred. The physical characteristics of the whistles are well adapted to these environmental limitations because they allow a strong power in a narrow range of frequencies (1000 to 4000 Hertz) that corresponds to the best human audibility and sound discrimination. Moreover, this whistled frequency band is higher than the frequencies which are typically the most powerful in underlying characteristics of all natural background noise (emphasizing low frequency contents). Additionally, human whistled signals incorporate several acoustic properties that help compensate for signal distortions and noisy interferences. For example, similarly to modal speech, they include enhanced spectral peaks for vowels, rapid spectral changes for consonants and amplitude modulation patterns to highlight informative portions such as vowel-consonant alternations. As a result, they represent strong and clear signals, little disturbed by natural ambient noise and physical 
obstacles that affect the propagation of sound, increasing significantly the audible range of oral speech (going much further than a shout) and thus preventing the interlocutors from traveling long distances to talk to each other. When a whistled signal is blurred by echoes or atmospheric turbulence as it traverses mountains or vegetation, it remains quite coherent with its original form because of its simple, unique and modulated narrow frequency band carrying information. Because whistled speech is highly detectable through ambient noise, it is very efficient and often used in difficult weather conditions (fog or dense weather, rain ... see examples on Chinantec in Sicoli $(2012,2016))$. Whistled speech was also sometimes found in very noisy environments, such as the marketplace in the Mazatec town of Huautla de Jimenez in Mexico, or on the shores of a river in the valleys near the Turkish village of Kusköy (Meyer 2005), or in dense tropical forests (see also next paragraph). It is also quite common to use it at night.

\section{Specificities of the practice in each type of habitat}

The vegetation in dense tropical forests and savannas restricts visual contact and limits the propagation of sound. In such contexts, whistled speech frequencies are also well shielded against acoustic energy loss due to reverberation, which is particularly important in densely vegetated environments, as the whistled frequencies belong to the most favorable frequency window-ranging from $1 \mathrm{kHz}-3 \mathrm{kHz}$-where reverberation in forests is shown to vary less with distance (Padgham 2004). In dense vegetation, whistled language facilitates the coordination of individuals during group movements, especially during hunting and fishing (Figure S2). Whistling also allows human dialogue to go undetected by animals, blending in with natural sounds since many animal species also use whistling. Other advantages are that whistles are easy to locate and difficult to recognize to strangers (especially other tribes, even speaking different dialects of the same language). Whistled 
communications are used from about 10 meters and up to about 500 meters, depending on the density of vegetation.

In mountains, the topography necessitates speaking at a distance by increasing visual range, favoring scattered settlements and hindering easy travel between any two points, and by creating large open spaces favorable to signal transmission. For example, valleys create real wave guides, whereas altitude differences contribute to good signal propagation. In El Hierro and La Gomera Canary islands, in the region of Kuskoy in Turkey, in the high Atlas or in the Pyrenees near the village of Aas, two points only 500 meters apart can easily represent an hour in walking time. Thus, whistled forms of languages serve as soon as the spoken form becomes ineffective; between 40 and 100 meters, depending on the terrain. It can be heard up to several kilometers away in some valleys. For example, in the Pyrenees, the distances of use of the whistled Bearnese were up to 2 kilometers (Busnel 1964). In the Canary Islands, steep valleys allow whistlers to reach distance records, as they constitute authentic waveguides that carry the signal up to, sometimes, about 8 kilometers (Busnel et Classe 1976). In all these places, it was always found to be connected with pastoral and agricultural activities, where it serves to hail a person, to give an order, to transmit news or to draw attention to an unusual situation. Shepherds use it extensively because they escort the flock in high mountain pastures and need to exchange information with their distant village or with other shepherds. In mountains near the Black Sea (where Turkish is spoken), shepherds and tea or peanut gatherers have been observed to whistle the entire day, giving indications, instructions, news, conversing about the weather, joking and even reciting newspaper headlines. 


\section{Different whistling techniques}

A single person can use several techniques but some of them are more frequent in each place, depending on the most common distances of communication, which are influenced by the terrain and other contexts of use such as the most common subsistence activities linked to whistled speech. Ecological environments influence the choice of the technique given that distances covered in closed dense forest are generally shorter than distances covered in open mountains (less acoustic degradation and more opportunities due to an increased visual range in open areas). Techniques associated to very long distances of communication are more often practiced in open habitats. Bilabial technique is less powerful and mostly used in forests for communication both outside and inside villages, it may be used inside villages or at close range in open areas. Hand resonance techniques were also found principally in forests. In the Amazon rainforest, we found mainly the bilabial technique and techniques with (a) resonant hand(s) in front of the mouth to lower the whistle frequency, which guarantees a better propagation in biotopes characterized by dense vegetation by targeting the less reverberant window described earlier (see more details and photos in Supplemental materials Text S1 and Figures S3, S4, S5, S6).

\section{An adapted speech type highlighting human ecological niches}

All the factors described until now support the view that whistled speech represents a language practice particularly well adapted to the most frequent and pervasive environmental constraints that affect acoustic signals in outdoor rural contexts, which have been the dominant setting for the vast majority of human evolution until very recently. Whistles are probably the best signals that can be produced by the human vocal tract to convey messages with good consistency over a distance. They even constitute an energysaving substitute for movements across and within lands and even sometimes for visual communication that may be screened by obstacles or blurred by distance. These ecological 
features seem to represent at least one of the necessary conditions of the existence of whistled speech communication systems, if not their invention through necessity. Importantly, ethnographic and bioacoustic studies in widely diverse populations provided data showing special interactions and associations among the following three levels at which the whistled language practice was observed: (a) the biotope where human whistlers live, (b) the most recurrent social/subsistence activities using whistled speech and (c) the corresponding whistling techniques. Indeed, different constraints inherent to the habitats contribute to select prevalent activities that are undertaken by the local populations to make their living. Whatever the multiple contexts in which whistled speech is used in each place, the people who engage in this mode of communication principally make their living as shepherds or goat herders, hill cultivators or game hunters. In each place, the most popular whistling technique is always correlated with such dominant food-supplying activities, which are themselves partially dictated by the landscape. In each place, the prevalent activity is associated with an average range of communication which is more conveniently reached by some specific whistling techniques. For example, a landscape characterized by dense vegetation favors hunting activities. It does not mean that agriculture is not practiced in these landscapes but instead that hunting is the activity that employs/requires most whistling because of the constraints of distance communication and secrecy of communication toward animals (and in some cases, rival tribes) that are inherent in hunting. Note that the singing mode of whistling, which is generally practiced by bilabial whistling or with a tool-a leaf or a flute- does not fit this classification because it is influenced by the relation to music for parts of the whistled repertoire (see also Text S2, Supplemental Material). 
These observations offer interesting insights because they suggest that a whistled language is strongly impacted by different ecological niches and by how human subsistence activities adapt to local biotopes. Therefore, the worldwide observation of whistled languages underlines that information and communication, which play important roles as drivers of cultural evolution in modern societies (Finke 2005, 2006), may have sometimes been deeply affected throughout history by environmental contexts in small rural societies. This aspect, which has been little addressed to date in the work on human ecology is interesting to point out the importance of ecosystems in the evolution of some characteristics of human language (Meyer 2015), which until now has been mostly investigated in relation to lexical contents of languages or to language vitality.

\section{Linguistic typology of whistled speech}

The significant diversity of languages that were found to be naturally whistled offers the possibility of tracing the essential typological linguistic distinctions associated to this special natural speech type and their implications for speech processing and research in general in language sciences. Here, we present a general sketch of the phonetic and phonological strategies employed by traditional whistlers to transpose their language into whistles, based mostly on the languages on which we could work directly through recordings, but always mentioning important research in the domain dealing with other languages. Throughout our inquiry, the most notable similarities between otherwise unrelated whistled languages have been observed in a wide range of tonal languages (e.g., Hmong, Akha, Mixtec, Mazatec, Gavião, Suruí, Ewe) and non-tonal languages (e.g., Greek, Turkish, Spanish, Béarnese, Wayãpi, Tamazight) which were found to respectively follow either pitch-based or formantbased whistling strategies. We also identified a small group of languages, all classified as 
non-tonal, that adopt intermediate strategies and where whistlers apparently found a balance between the contribution of pitch and formants (e.g., Chepang, Siberian Yupik). The systematic comparison of the spoken and whistled forms of speech in various languages enables us to show how pitch-based, formant-based and intermediate whistled transposition strategies adapt to the phonemic inventories of each particular language. Our analyzes support that the whistled form of a language doesn't define a phonemic system independent from the spoken form in spite of the phonetic reduction at play; instead, we argue that whistled speech recognition is not essentially different from whispered speech recognition or degraded speech recognition which rely on cognitive reconstruction from a reduced speech signal. The reduced semiotic carrying capacity of the whistled channel which is due to the drastic phonetic reduction applied by the whistled modality of speech motivates adaptations at every level of language communication. It has therefore been so far the occasion to revisit several branches of language sciences. Questions concerning whistled phonetics and its interaction with phonology have attracted a great deal of research effort. Research on cognitive processes highlighted by whistled language decoding began later and we will therefore mention them more rapidly (see also Text S5 in Supplemental Materials), finally less research has been addressed on other topics such as syntax or conversational aspects, except one study on whistled Chinantec repair problems showing that repair in whistled speech shares the same universal sequence organization as repair in spoken speech, but that there are noteworthy differences in the preference organization and the typology of repair in whistled speech (a reduction in the types of repair initiations; a lack of preference for self-initiated repair; and an inversion of the frequency relation of open and restricted repairs to favor open formats). These patterned differences are motivated by a reduced semiotic carrying capacity of the whistled channel (Sicoli 2016). 
All together, the studies that we present here confirm a point underlined by Sicoli in his paper: studies of language channeled through different modalities such as whistled speech shed a new light on our understanding of human language more generally.

\section{General aspects of the linguistic typology}

Whistled speech profoundly modifies the phonetics of modal speech, applying a reduction at the source and in the frequency domain: transforming the complex and multidimensional frequency spectrum of spoken speech into an imitation based on a simple monodimensional variation of the whistle (Figure 2, Figure 3). This means that during the procedure of whistled speech production, certain phonetic details present in modal speech are inevitably lost. Whistles are produced in the anterior oral part of the mouth in which they are tuned and modulated in frequency, which means that the source and the resonator are here not independent.

When comparing the whistled versions of several languages of the world, we observe that each one conforms to several aspects of the language that is being transposed. A major difference in the strategy of spoken-to-whistled substitution has been observed between tonal languages (Figure 3) with respect to non-tonal languages (Figure 2).

The acoustic structure of spoken vowels and their production mechanism allows us to explain the main typological distinction between tonal and non-tonal languages for whistled speech: as we just began to explain above, spoken vowel production is characterized both by a clear fundamental frequency and source of the sound that results from the vibration of the vocal cords at the bottom of the larynx (also called F0, which encodes the lexical tone when it happens in tonal languages, and also sometimes stress/intonation in several languages) and a clear resonant structure of the vocal tract (the formants that organize the vocalic 
space of each language, for example). These two frequency levels are largely controlled independently (Fant 1960), and can function in the human mind as separate channels of information, particularly to encode speech, because they are also independently and perceptually recoverable through pitch (based on F0) and timbre (based on the full spectrum of the voice, including the formants) (e.g. Risset 1968, Stevens 1998). In this sense, modal spoken speech contrasts with a whistled speech, in which it is not possible to control the F0 and the resonance separately, since they are produced together in the vocal tract. In fact, in whistling, the F0 of the whistle is also the frequency corresponding to the resonance in the oral part of the vocal tract.

Thus, while tone and vowel quality can be conveyed simultaneously by the two perceptual frequency levels carried by spoken speech, the transformation into whistles forces the whistlers to choose between the two to encode linguistic information (tone or timbre). Whistlers solve this dilemma differently as a function of the phonological role of pitch in their language. In most non-tonal languages there is not much concurrence between the two perceptual levels because pitch does not carry much lexical information, as it does in the tonal languages. Two clear main strategies of spoken to whistled speech transposition emerged naturally from this distinction: pitch based vs. formant based whistling.

- In most non-tonal languages, in what is called 'formant-based whistling,' whistlers carefully approximate the vocal tract articulation used in the spoken form. As a consequence, the pronunciation of whistled vowels and consonants is in direct relation to the specificities of the vocal tract maneuvers occurring in spoken speech (but with a reduced amplitude of movements as they have to be achieved while maintaining a whistle source in the anterior oral part of the mouth). This approach results in a whistled transposition of vowel and consonant qualities which are 
originally carried by the complex frequency spectrum of spoken speech (more precisely by some of the main resonances of the sound in the mouth, called formants; we develop this point in detail later in this paper). This means that whistlers traditionally learn to transform the complex perceptual attribute of timbre resulting from human voice into a simple modulated frequency line. For language scientists, it is a challenge to understand how this transformation works both in production and in perception. Indeed, strikingly, the whistled phonetic details that are selected during this procedure are sufficient for trained whistlers of non-tonal languages to recognize non-stereotyped sentences and also to achieve a reasonable degree of word and syllable recognition. For example, in their seminal study on whistled Turkish, Busnel and colleagues showed that words are recognized at a rate of approximately $70 \%$, whereas common whistled sentences are recognized at a rate of approximately 80-90\% (see Busnel 1970, Moles 1970, and Meyer 2015, for a review). For all these reasons, we will describe this typological category more thoroughly in the next subsections (with additional explanations and details in Supplemental materials (see Text S4, Figures S7, S8, S10, S11, S12, S13, S14)).

- In tonal languages (see Meyer 2005, Rialland 2005 and Meyer 2015 for reviews), in what is called a pitch-based whistling, the situation is different: the whistles do not focus on imitating the timbre of speech, but the pitch of the voice, transposing the fundamental frequency of the vocal folds to encode mainly the lexical tones. Thus, they conform principally to the surface expression of lexical tones. The tonal line and whistles share a common, quintessentially prosodic nature that most probably explains their direct association when a tonal language is transposed into whistling: 
as if the tonal phonological entity attracted the whistled pitch. The first striking consequence is that whistlers emulate the productions originally made in the larynx (in modal speech) with the oral articulators producing whistles. Thus, they proceed to a qualitative transfer in the articulatory behavior. This is made at the cost of vowel quality (originally encoded by timbre), which is completely excluded from the whistled imitation. The second striking consequence is that this exclusion of timbre occurs even when the functional load of information carried by tones is lower than the one corresponding to segmental aspects carried by the timbre (Bagemihl 1988). The direct drawback is that the possibility to transmit complex sentences to a trained listener depends on the informational load carried by tonal prosody in this language: for example, it is much higher in the Hmong language (7-8 contour tones depending on the dialect) than in Surui (two level tones). This is the reason why, in tonal languages with few informational load on tones, sentences are more formulaic and therefore more predictable, while high levels of intelligibility can be reached on unpredictable sentences in tonal languages with a rich tonal system for lexical load such as Chinantec (see examples on Chinantec in Sicoli (2016)). In addition to tone, which is rendered by pitch patterns, basic segmental information is rendered by the amplitude envelope of whistled tonal languages. Vowels remain more energetic than consonants, and, in general, two distinct classes of whistled consonants exist as a function of the continuity of the whistle (in intervocalic position): a continuous or near continuous signal (for nasals, liquids, glides; which always show a partial closure of the articulators, which explains why they sometimes appear as near-continuous (such as /n/ in the word /ini/ of Figure 3)), versus a clearly interrupted signal (for obstruents, see for example /t/ of Figure 3, or /t/ in Figure S9). Other fine temporal 
aspects resulting from the amplitude envelope were found to render consonant closure durations, and may help whistlers to separate consonants into various classes in accordance with what happens in spoken speech. For example, voiced consonants are whistled with a shorter closure than voiceless (Meyer 2015). Differences were also found between different whistling techniques. For example in Gavião of Rondônia, the bilabial whistling technique was providing more details than the hand whistling technique, mostly for palatals and dentals for which clear pitch modulations were observed (Moore and Meyer 2014, see also /t/ in Figure S9 (and Audio S9a,b,c), Supplemental Material).

- In addition, just as the distinction between tonal and non-tonal languages is sometimes difficult to establish in spoken languages, similarly, there is a category of languages for which the whistlers adopt intermediate strategies and seem to jump from the pitch based to the formant based whistling strategies. Few languages seem to belong to this intermediate category and the reasons why they adopt such type of strategy is probably due to the important phonological role played by stress and/or intonation in their structure. Up to now, two of them have been partially studied, Siberian Yupik (Meyer 2008) and Chepang (Caughley 1976). The frequency scale of whistled vowels in both Chepang and Siberian Yupik still shows some evidence of contributions from the underlying influence of the formant distribution to whistled pitch, but it does not have the systematically dominant influence as in Turkish, Greek or Spanish, for different reasons in each language. A first group is formed by /i/ only: its formants 'pull' the frequencies of the vowel quality towards higher values so that /i/ generally remains high in whistled pitch even if, in some configurations this 
tendency appears to be disturbed by prosodic context. Next, the group formed by the vowels /e, a, u/, which have intermediate frequency values in the whistled scale, is more dependent on prosodic contexts in both languages, and of consonantal context in Chepang. Finally, the group formed by /o/ alone in Chepang pulls frequencies to lower values but may also be dependent on the prosodic context. Siberian Yupik has also a schwa that is largely dependent on consonantal context (Details on the particular whistled behavior of schwa will be provided later in this article for Tamazight language).

Finally, for all types of languages, whistlers adapt their whistles to the number of tones and eventually to specific modulations/contours between/inside tones (in tonal languages) or to the number of vowels and eventual important phonological intonation effects (in non-tonal languages), and how these tones or vowels are co-articulated with the consonants. Consonants are whistled by performing frequency and amplitude modulations of the whistled frequencies that surround them, in all typological categories. For example, when the amplitude modulation shuts off the whistle to emulate rapid amplitude modulations of modal speech, whistled consonants are characterized by silent gaps (such as in /t/ in Figure 2 or $/ \mathrm{t} /$ and $/ \mathrm{k} /$ in Figure 3). Thus, in intervocalic position, whistled consonants are represented by continuous, near continuous or interrupted modulations of the whistles (see Figures 2 and Figure 3, but also all spectrograms and listen to audio files available in Supplemental materials).

\section{The multi- to mono-dimensional transformation of formant-based whistling} One of the most striking aspects of whistled languages concerns formant-based whistled speech as it shows the possibility to reduce the spoken phonetic complexity encoded in 
timbre and its resulting formant distribution into a single whistled stream that transposes vowel and consonant segments while remaining intelligible.

In this category of languages, Classe (1956), was the first to note that the points of articulation targeted by the tongue during the pronunciation of consonants in Silbo Spanish are similar to those of spoken Spanish. He did not provide any graphical, recorded or mathematical proof, but he explained that he was taught to articulate this way by the whistlers who guided his training in whistled speech. Next, since early studies in the $70 \mathrm{~s}$ several descriptions have noted that whistled speech signals bear frequency shapes similar in several aspects to the 2 nd formant of spoken speech, which occupies a central space in the vocal tract. Leroy (1970) was the first to systematize this kind of observation (on Turkish language of Kusköy) by comparing and analyzing spectrograms of the whistled and spoken formant transitions. The same parallel was later noted in Spanish by Brusis (1973) and Busnel \& Classe (1976). Rialland (2005) extended this view on Spanish by describing the same phenomenon in detail, and by affirming that only formant 2 is transposed from spoken speech to whistled speech, even if she found counterexamples but attributed the observed discrepancies to the fact that "Silbo [whistled Spanish] utterances do not simply copy F2 transitions but involve partly conventionalized patterns" (p. 243).

Comparative description of different languages confirms that F2 is effectively a key acoustic cue for comparing whistled speech and modal speech, but also that there is evidence that F2 is not the whole story, without the need to postulate for conventionalized patterns. Typically, the detailed description of the vowel system of languages with a rich vocalic system, such as Turkish (Meyer 2008, 2015) do not support the idea that only the 2nd formant is transposed from modal speech to whistled speech. These studies rather suggest 
looking at upper formants such as F3 of F4 for some front vowels (such as $[\mathrm{Y}]$ and $[\dot{\mathrm{H}}]$ in Turkish, see the detailed analysis in Supplemental materials (Text S4) and in Figure S7).

Interestingly, results on articulation converge with these results. From the perspective of articulatory description, the parallel between F2 and whistling is not surprising because the acoustic resonance of the articulated whistled signal occurs primarily in the front oral cavities of the reduced vocal tract, which correspond approximately to those that play an important role in defining the upper formants of standard speech (above the 1st formant). However, the few descriptions of the production mechanism of whistles that were made so far for the bilabial whistle technique have shown that a whistle frequency is always captured by the second or the third formant of the vocal apparatus, and that a frequency jump occurs between the two when these formants are close (Shadle 1983). Typically this concerns front vowels (such as /i/) and some consonant transitions.

\section{Vowels}

Systems of whistled vowels follow the same general organization in all the non-tonal languages. For example, in Greek, Spanish, and Turkish, whistled vowels are emitted at different pitch levels depending on the frequency distribution of their timbre in the spoken modal speech form (i.e., typically, /i/ has a high pitch, /e/ lower, /a/ even lower, and /o/ is among the lowest possible whistled frequencies (Meyer 2005, 2008, Díaz Reyes 2008) as shown in Figure 2 (and corresponding audio files in Supplemental materials AudioFigure2a,b), Figure S7 and Figure S10 (Audio S10a,b). For a given distance of communication, a given whistling technique and a given whistler, each vowel is whistled within a specific interval of frequency values covering the variability of articulation of the corresponding vowel position. Importantly, in whistled speech, each individual whistled vowel is much more relative than in spoken modal speech because it depends solely on a 
simple frequency value approaching the characteristics of a simple sinewave. The identity of a given vocalic position (for example /a/, /i/ and /o/ in Figure 2 and Figure S10) can be ascertained only when confronted to other vocalic positions of the same language. Moreover, whistled frequencies can vary with the technique (bilabial whistle, finger whistle...) but also the physiology of the whistler and the power of whistling. For example, the farther the whistlers have to communicate, the wider and the higher is the whole scale of the vocalic frequencies, /i/ staying below $4 \mathrm{kHz}$ and the lowest vowel around $1 \mathrm{kHz}$ (Meyer 2005, 2008). This is the reason why we generally study whistled productions of different whistlers separately, and even take care to group productions of a same whistler only if they were produced with the same whistling technique. Tamazight language provided the occasion to study the whistled frequency distribution associated to schwa and to find that they depend on the locus of articulation of the neighboring consonants: coronals modulate towards high frequencies; labials, labiodentals and uvulars modulate towards low frequencies (Meyer et al 2015, see more in Text S4 of Supplemental materials, and in Figure S11 and corresponding AudioS11a,b). This suggests a principle of phonetic inertia: as for vowel-like elements in spoken forms, the presence and quality of [@] results from the gestural timing configuration of the surrounding consonants (Dell \& Elmedlaoui 2011, Ridouane \& Fougeron 2014).

In previous works, we analyzed the frequency distribution of whistled vowels in various nontonal languages that were recorded during our field inquiry (Meyer 2008, Meyer 2015, Meyer et al. 2015). We found that each full vowel position is whistled in a definite frequency interval and that each whistled language has its own characteristic frequency distribution of whistled vowels, which is related to how spoken vowels are articulated in each language. Moreover, depending of the language, whistled intervals of frequency of different vowels 
may overlap. In some cases, two whistled vowels may greatly overlap up to the point that their frequency values are not statistically different. Such whistled vocalic spaces are provided Greek, Spanish, Tamazight and Turkish are provided in Supplementary materials.

It is important to note, though, that the reductions that were observed and quantified statistically in groups of frequency neighbors do not necessarily mean that whistlers mentally assimilate the whistled vowels of the same statistical group. Indeed, traditional whistlers all attest that they try to articulate words while thinking of them as they are normally spoken. This suggests that they never switch to a different phonological pronunciation as they do not attribute a phonological value to these whistled phonetic reductions. Some articulatory cues even confirm this. For example, the rounded vowels are still produced with a slight rounding movement of the lips; not enough to produce an acoustic effect on the whistled signal, however, because the lips are kept very tight to produce a strong whistle. We will see several examples going in this direction regarding consonants (next subsection).

In terms of perception, it has been recently demonstrated that this type of distribution of whistled vowels on a simple frequency scale corresponds to a perceptual reality that allows discriminating the vowels between them not only for competent whistlers in a whistled language, but also for listeners without any knowledge about this phenomenon, with an influence of their language background (Meyer et al. 2016, Meyer et al. 2017). Thus these studies show that individuals adapt both in production and in perception to the pronunciation specificities of each vowel in each language, and that the whistled systems rely directly on phenomena already at play in modal spoken speech (see more details on this topic and other perceptual processes of whistled speech in Text S5, Supplemental materials) 


\section{Consonants}

With some language-specific differences due to the particularity of articulation of consonants in each language, the whistled systems of consonants also follow the same general organization in all of the non-tonal languages. Phonetic consonantal similarities were observed between consonants with close manner and/or place of articulation. These were sometimes called reductions Typically, the whistled frequency shapes of consonants often resemble the frequency shapes of the formant transitions of the 2 nd formant and/or the 3 rd formant of modal speech (for the place of articulation), and they encode a similar dynamics of the signal amplitude envelope (for the manner of articulation) (Classe 1957; Leroy 1970; Meyer 2005, 2008; Rialland 2005). It must be noted here that the precision that is attained in whistling to render consonants, and thus the groups of supposed reductions, is partly dependent on the whistling technique that is employed by the whistlers. In the Canary Islands, the most widespread technique is the bent index finger which leaves less possibilities to articulate labials than the linguo-dental technique that is the most commonly used in Kusköy (Turkey), Antia (Greece) and the Moroccan Atlas (Meyer 2015). Another factor influencing the precision of realization of the consonants is the proficiency of the whistlers, which is very disparate in situations of whistled speech endangerment. Generally speaking, in any case, both the simple whistled signal and the constraints of articulation due to whistling contribute to enhance drastically the phonetic similarities of consonants already at play in the spoken form.

Two clear distinctions appear among the consonants in non-tonal languages: one between continuous and non-continuous whistled consonants and one between consonants with high or low whistled loci. The continuous whistled consonants are the liquids (see /// in Figure 2), the approximants /j/ and /w/, the pseudo fricative /h/ (which appears for example in Turkish 
(Meyer 2015)) and sometimes, /n/. In most previous studies (Rialland 2005, Meyer 2015), the fricative sounds of dental and labial fricatives are not found to be whistled at all, and they are often found as non-continuous. However, this also depends on the rate of speech: in rapid whistled speech, such fricatives may recover their continuous aspect (Meyer 2015). Concerning loci, consonants with high whistled loci in intervocalic positions almost always correspond to rising whistled transitions of the frequency of the vowel preceding the consonant and to subsequent falling transition towards the frequency of the vowel following the consonant, transitions, whereas consonants with low whistled loci correspond systematically to falling (before consonant)-rising (after consonant) transitions. The values of the consonant loci of spoken speech may be modified in whistling due to different articulation constraints and a different nature of the signal that is resonating in the reduced vocal tract. In Spanish, two high loci were described: an extra high for sibilants and affricates and a high for other dentals (Rialland 2005), whereas three high loci were identified in Turkish (mid-high for velars, high for dentals and extra high for sibilants and affricates) (Leroy 1970, Rialland 2005). With respect to Greek, a unique high locus was found for all dentals (see, for example, $[\theta, t]$, Figure 2). However, in rapid whistled speech, the loci of dentals that are continuous in slow whistled speech are often lowered to a mid, whereas the loci of the dentals that are non-continuous are not lowered (Figure S12) (Meyer 2015). Conversely, mid-high loci were found for velars $[k, \gamma]$ associated with $[i, \varepsilon]$, whereas low loci

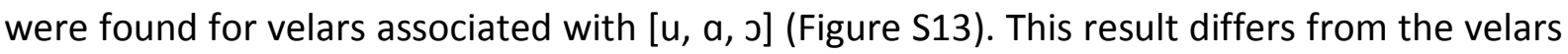
as whistled in Turkish (mid-high loci for all vowels) and Spanish (low loci for all vowels) (Meyer 2005; Rialland 2005). For Greek labials, a unique low locus was found, which corresponds to what happens in whistled Spanish and Turkish labials. 
With respect to the manner of articulation, a distinction between voiced and unvoiced stops was formerly identified in Spanish and Turkish (Meyer 2005, Rialland 2005), in Greek (Meyer 2015) and in Tamazight/Tashlhiyt (Meyer et al. 2015, Meyer et al. 2019): voiced stops manifest generally in whistling with a more gradual amplitude envelope in the signal and/or a shorter complete consonant closure than unvoiced stops. The gradual amplitude envelope also characterizes labial fricatives such as /f/ and /v/ along with nasals (see Meyer 2015, p.116-117). As explained earlier, the groups of phonetic consonantal reductions would have been slightly different if we had considered a quicker rate of whistled speech. In this respect, the difference between dental stops and dental sibilants in rapid whistled speech shows that the whistlers do intend to articulate them differently, even if they are difficult to distinguish on spectrograms at a slower rate.

Tamazight and Tashlhiyt which are whistled in the high Atlas are of great interest for exploring further how rich consonantal systems can be whistled, with complex clusters of consonants, an optional schwa-like element and a syllable structure often cited as typologically unique because it allows any segment to be a syllable nucleus (Ridouane 2014, Figure S11). We found that Tamazight clusters are not only maintained but are over articulated making schwa elements within them highly discernable. This over articulation is not essentially different from what occurs in shouting: when consonants within a cluster display a low degree of gestural overlap and longer delay between events, a period of no constriction occurs that is overtly realized as a vowel-like element in the signal. While in whistled Turkish, Greek or Spanish, consonant clusters resulting from two consecutive syllables concatenate the frequency shapes of each constituent by truncating them at their encounter (e.g. Greek [ksp] simplified into [kp] (Meyer 2015, see Figure S12)). The way Tamazight/Tashlhiyt consonant clusters are whistled probably reflects the underlying 
syllable structure of these sequences, as shown by the fact that a form like $[\mathrm{k} / \mathrm{m}]$ is partitioned in two parts, and that differences between light and heavy syllables are quasi systematically rendered (Meyer et al. 2015, see Figure S11). Whistled Tamazight was also the occasion to explore geminate consonants (Figure S14, Audio S14) and the status of covarying features or secondary features to sound contrasts in order to investigate whether they are deliberately controlled by the speakers, or contingent automatic effects required by the defining features. Results show that Enhancement Theory (Stevens and Keyser 1989, Keyser and Stevens 2006) offers a basis for accounting for the variable acoustic attributes defining the singleton/geminate contrast in both normal and whistled Tashlhiyt as, interestingly, secondary features are also conveyed in geminate whistling of this language (Ridouane et al 2018).

\section{Conclusion and perspectives}

A whistled language is the result of the adaptation of human productive and perceptive flexibility in speech communication to environmental, cognitive and linguistic constraints. This natural type of speech, which exists in a large diversity of local rural populations, developed properties of a real telecommunication system mostly for distance and withoutsight talk in natural surroundings, particularly for traditional subsistence activities involving hunting, pastoralism and agriculture (food supply subsistence activities). Just like for language in general, we know very little about the origin of this ancient practice which radically transforms the phonetics of humans' most elaborate and specific communication system. However, these socio-ecological features seem to represent at least one of the necessary conditions of the existence of whistled speech communication systems, if not their invention through necessity. Crucially, the exploration of this phenomenon and the 
typological comparison of its expression in a large diversity of languages provide a very fruitful scientific object to question classical language descriptions, to test linguistic theories or to open new perspectives in language sciences. Whistled forms of languages challenge very deeply key concepts of linguistics such as the phonetic/phonology relation, the notion of prosody (the purely prosodic melodic line of whistled speech sometimes encodes primarily formants), as well as the notion of syllable. It also questions the music-language relation as it may be also expressed in a singing mode in some languages. Finally, the fact that whistled languages induces much more phoneme confusions than modal speech obliges cognitive scientists to adapt their protocols and methodologies (see for example Meyer et al 2019) to exploit fully their high potential in serving as tools to investigate perceptual processes of languages (see also Text S5 in Supplemental Materials).

\section{References}

Bagemihl B 1988. Alternate phonologies and morphologies. Ph.D. Dissertation. Columbia: University of British Colombia

Brusis T 1973. Über die phonetische Struktur der Pfeifsprache Silbo Gomero dargestellt an sonagraphischen Untersuchungen. Zeitschrift für Laryngologie 52, 292-300

Busnel R-G. 1964. Documents sur une langue sifflée Pyrénéenne. Paris : SFRS

Busnel R-G. 1970. Recherches expérimentales sur la langue sifflée de Kusköy. Revue de Phonétique Appliquée, 14/15: 41-57.

Busnel R-G, Classe A. 1976. Whistled Languages. Berlin: Springer-Verlag.

Caughley R. 1976. Chepang whistle talk. In T. Sebeok T, D.J. Umiker-Sebeok (Eds.). Speech surrogates: drum and whistle systems (pp. 966-992). The Hague: Mouton.

Classe A. 1956. Phonetics of the Silbo Gomero. Archivum linguisticum 9, 44-61.

Classe A. 1957. The whistled language of La Gomera. Scientific American 196, 111-124.

Cowan G. 1948. Mazateco whistle speech. Language 24, 280-286. 
Dabelsteen T, Larsen ON, Pedersen SB. 1993. Habitat-induced degradation of sound signals: quantifying the effects of communication sounds and bird location on blur ratio, excess attenuation, and signal-to-noise ratio in blackbird song. The Journal of the Acoustical Society of America, 93, 2206-2220

Dell F, Elmedlaoui M. 2002. Syllables in Tashlhiyt Berber and in Moroccan Arabic. Dordrecht: Kluwer.

Díaz Reyes D. 2017 (2008). El lenguaje silbado en la Isla de El Hierro (segunda edicion ampliada), Tenerife, Le Canarien ediciones, La Orotava.

Eboué F. 1935. La clef musicale des langages tambourinés et sifflés. Bulletin du Comité d'étude historiques et scientifiques de l'Afrique Occidentale Française 18, 353-360.

Fant G. 1960. Acoustic Theory of Speech Production. The Hague: Mouton \& Co.

Finke P. 2005. Die Ökologie des Wissens. Exkursionen in eine gefährdete Landschaft. Freiburg/Munich: Alber

Finke P. 2006. Die Evolutionäre Kulturökologie: Hintergründe, Prinzipien und Perspektiven einer neuen Theorie der Kultur, Anglia 124(1), 175-217.

Junzo K. 1998. La voix, étude d'ethno-linguistique comparative. Paris: EHESS.

Keyser SJ, Stevens KN. 2006. Enhancement and overlap in the speech chain, Language 82(1), 33-63.

Larsen ON, Radford C. 2018. Acoustic conditions affecting sound communication in air and underwater. In H. Slabbekoorn, R. J. Dooling, A. N. Popper \& R. R. Fay (Eds.) Effects of Anthropogenic Noise on Animals. New York: Springer Handbook of Auditory Research 66, pp. 109-144.

Leroy Ch. 1970. Étude de phonétique comparative de la langue turque sifflée et parlée. Revue de Phonétique Appliquée, 14/15, 119-161.

Loh J, Harmon D. 2014. Biocultural diversity: threatened diversity, endangered languages. WWF Netherlands, Zeist : The Netherlands.

Lombard, E. (1911). Le signe de l'élévation de la voix. Annales des maladies de l'oreille, du larynx, du nez et du pharynx 37, 101-119.

Meyer J 2005. Description typologique et intelligibilité des langues sifflées: Approche linguistique et bioacoustique. Ph.D. dissertation. Lyon : Université Lyon 2.

Meyer J 2008. Acoustic strategy and typology of whistled languages; phonetic comparison and perceptual cues of whistled vowels. Journal of the International Phonetic Association, 38: 69-94. 
Meyer J. 2015. Whistled Languages. A Worldwide Inquiry about Whistled Speech Berlin: Springer.

Meyer J, Gautheron B. 2006. Whistled speech and whistled languages. In K. Brown (Ed.) Encyclopedia of Language and Linguistics 2nd Edition, vol 13 (pp. 573-576). Oxford:Elsevier.

Meyer J. Gautheron B, Ridouane R 2015. Whistled Moroccan Tamazight: phonetics and phonology. Proceedings of the International Congress of Phonetic Sciences 2015. Glasgow.

Meyer J, Dentel L, Meunier F. 2016. Categorization of natural Spanish whistled vowels by naïve Spanish listeners. Proceedings of Interspeech 2016. San Francisco, USA.

Meyer J, Dentel L, Meunier F. 2017. Categorization of Natural Whistled Vowels by Naïve Listeners of Different Language Background. Front. Psychol. 8:25 doi: 10.3389/fpsyg.2017.00025

Meyer J, Dentel L, Gerber S, Ridouane R. 2019. A Perceptual Study of CV Syllables in both Spoken and Whistled Speech: a Tashlhiyt Berber Perspective. Proceedings of Interspeech 2019, Graz, Austria pp.2296-2299

Meyer J, Meunier F, Dentel L, Do Carmo Blanco N, Sèbe F. 2018. Loud and Shouted Speech Perception at Variable Distances in a Forest. Proceedings of Interspeech 2018, Sep 2018, Hyperabad, India. Interspeech 2018, pp.2285-2289

Moles A. 1970. Etude sociolinguistique de la langue sifflée de Kusköy. Revue de Phonétique Appliquée, 14/15 : 78-118.

Moore D, Meyer J. 2014. The study of tone and related phenomena in an Amazonian language, Gavião of Rondônia. Language Documentation and Conservation, vol. 8.

Padgham M 2004. Reverberation and frequency attenuation in forests - implications for acoustic communication in animals. Journal of the Acoustical Society of America 115(1), 402-410.

Rialland A. 2005. Phonological and phonetic aspects of whistled languages Phonology 22, 237-271.

Ridouane R. 2014. Tashlhyt Berber. J. Int. Phon. Ass. 44(2), 207-221.

Ridouane R, Fougeron C. 2011. Schwa elements in Tashlhiyt word-initial clusters. Journal of Laboratory Phonology 2, 1-26. 
Ridouane R, Turco G, Meyer J. 2018. Length Contrast and Covarying Features: Whistled Speech as a Case Study. Proceedings of Interspeech 2018, Sep 2018, Hyperabad, India. pp.1843-1847

Risset JC. 1968. Sur certains aspects fonctionnels de l'audition. Annales des Télécommunications 23, 91-120.

Sebeok T, Umiker-Sebeok DJ. 1976. Speech Surrogates: Drum and Whistle Systems. La Haye and Paris: Mouton.

Shadle CH. 1983. Experiments on the acoustics of whistling. The Physics Teacher, 21(3), 148-154.

Sicoli MA. 2012. Sochiapam Chinantec Whistled Speech Archive. http://corpus1.mpi.nl/ds/imdi_browser?openpath=MPI1488119\%23.

Sicoli MA. 2016. Repair organization in Chinantec whistled speech Language 92(2): 411-432.

Stevens KN. 1998. Acoustic phonetics. Cambridge: MIT Press.

Stevens KN, Keyser SJ. 1989. Primary features and their enhancement in consonants, Language 65(1), 81-106

\section{Related Ressource List}

Meyer J. 2019. Whistled Speech as a tool for shepherds (demonstration in Whistled Spanish at the 'House of shepherds', Ecrins National Park, France). The World Whistles/Maison Du Berger/ Adaparle Project (UGA) https://vimeo.com/327303614

Meyer J, Dentel L. 2016. Whistled Speech examples in Greek Language. The World Whistles Production http://www.lemondesiffle.free.fr/whistled-Greek-Article-of-JulienMeyer.html

Meyer J, Ridouane R. 2019. Parler en sifflant dans les montagnes de l'Atlas : dialogue sifflé à longue distance en langue berbère tachelhit. (Speaking while whistling in the Atlas: whistled dialogs in Berber Tashlhiyt) A co-production CNRS - GIPSA-Lab/CNRS - LPP https://vimeo.com/361557210 
Yetman D. 2013. Whistles in the Mist: Whistled Speech in Oaxaca (Mexico). In D. Yetman (Ed.) In the Americas with David Yetman, Episode 20, Season 2 (Video Documentary). http://vimeo.com/57291304.

\section{Acknowledgements}

Special acknowledgements to Dr. Laure Dentel, Professor Busnel R-G., Professor Colette Grinevald, Dr. Fanny Meunier, Dr. Denny Moore, David Reyes Diaz, Dr. Rachid Ridouane, Dr. Damien Davy, Dr. Françoise Grenand, Professeur Pierre Grenand, Dr. Elissandra Barros and the speakers of various languages. The last 17 years of research on this subject were made possible thanks to the financial support provided by various institutions such as the Centre National de la Recherche Scientifique, the Fyssen Foundation (Post-doc grant, France), the Endangered Language Documentation Program (Post-doc project IPF0136, SOAS-University of London), the Conselho Nacional de Desenvolvimento Científico e Tecnológico (PDJ grant, CNPq Brazil), the European Union's Seventh Framework Programme for research, technological development and demonstration (EURIAS Fellowship, Lyon Collegium; Marie Slodowska-Curie Fellowship 630076, project Icon-Eco-Speech) and by prizes including a 2006 Rolex Award and the scientific prize of Paris-Jeunes- Aventures (Mairie de Paris). 
TABLES :

Table 1: Languages with the whistled modality reported in a research paper without any further study or recording (according to Meyer 2015)

\begin{tabular}{|l|l|}
\hline World regions & Languages \\
\hline Africa & $\begin{array}{l}\text { Attie, Bafia, Baïnuk, Bape, Birifor, Bobo, Burunsi, Goohwayoo, Gbaya, Gurma, } \\
\text { Lobi, Kabye, Kasem, Manjack, Marka, Mofu, Mwana, Nchumburu, Tshi, Ule, } \\
\text { Wobe, Yacouba, Yoruba }\end{array}$ \\
\hline Central America & Amuzgo, Chol, Otomí, Sayula popoluca, Totonac, Zapotec \\
\hline North America & Taos \\
\hline South America & Desano, Makurap, Siriono, Timbira \\
\hline Oceanía & $\begin{array}{l}\text { Aruek, Au, Bauzi, Binumarien, Gadsup, Palai, Tairora (in Papua New Guinea); } \\
\text { Punan busang (in Sarawak, Malaisia) }\end{array}$ \\
\hline
\end{tabular}




\section{Captions of Figures}

\section{FIGURE 1 :}

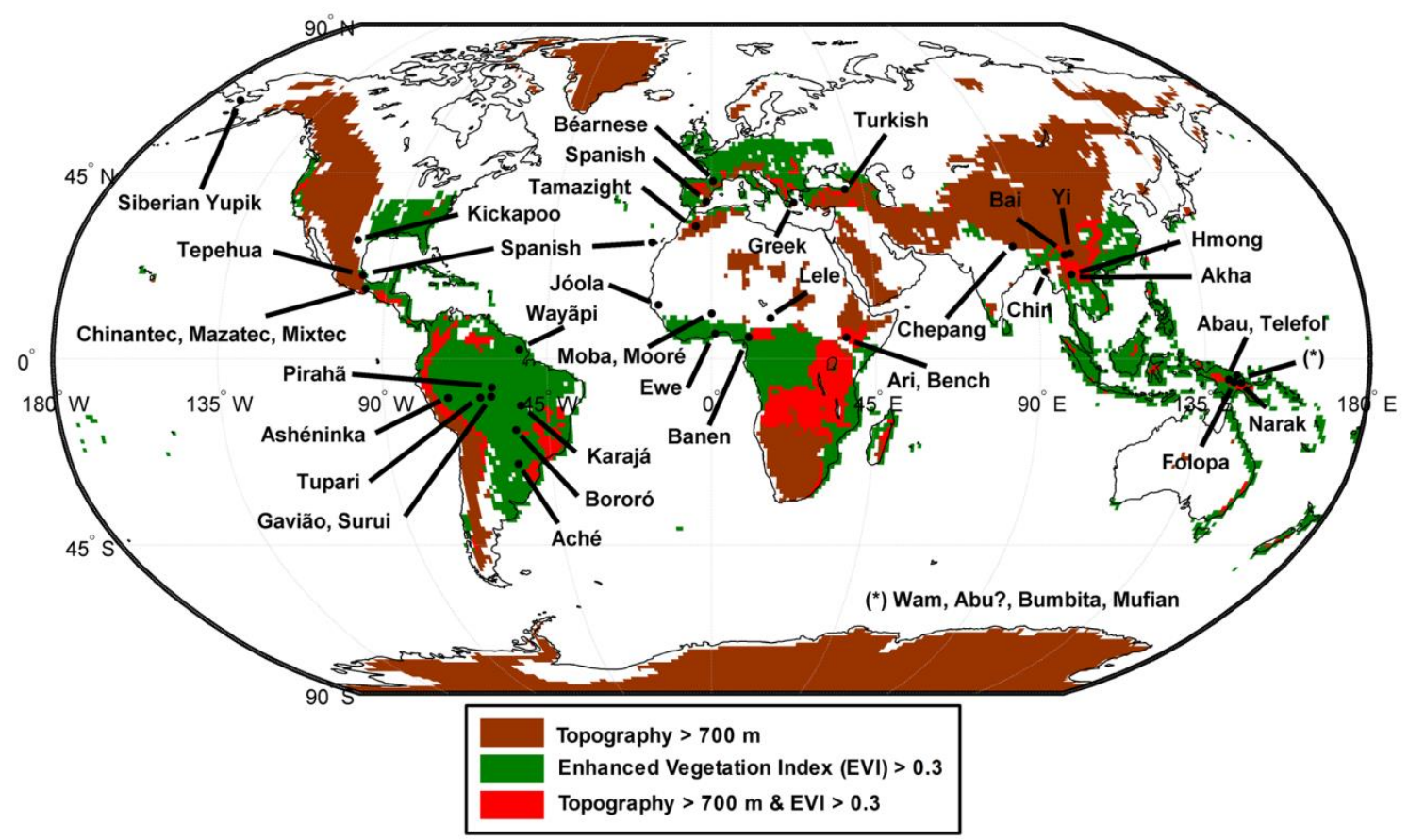

Figure 1: Map of the attested whistled languages in the world including indications of environmental features associated to mountainous and forested areas (topography, vegetation cover) (reproduced from Meyer (2015). Source for topographic data Atmospheric Infrared Sounder/Aqua level 3 Monthly standards physical retrieval (AIRS + ASMU), Goddard Earth Science Data and Information Services Center (GES DISC). Source for Vegetation data MODIS/Terra Monthly Vegetation Indices Global $1 * 1$ degree, NASA NEESPI data and service center. 


\section{FIGURE 2}

a
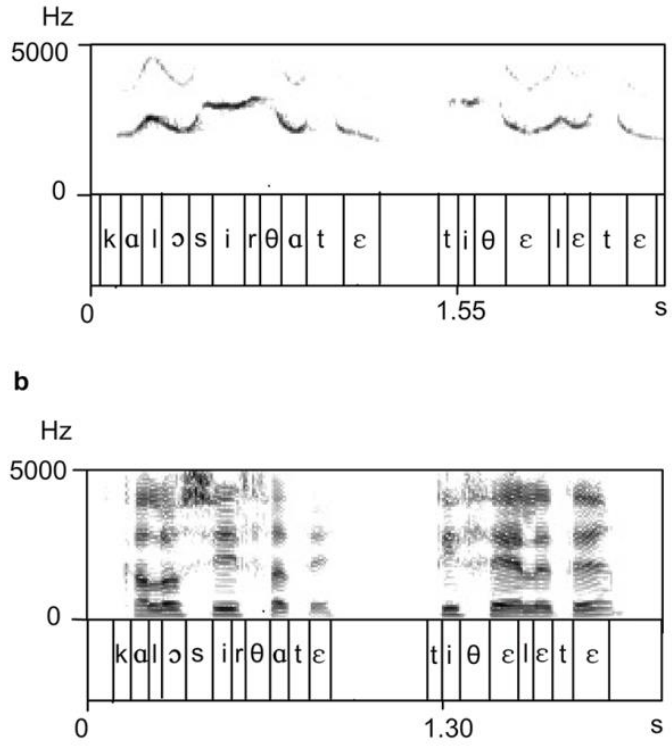

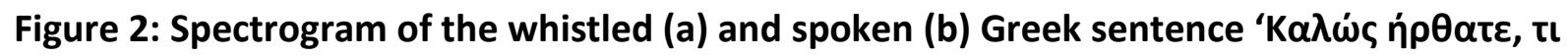

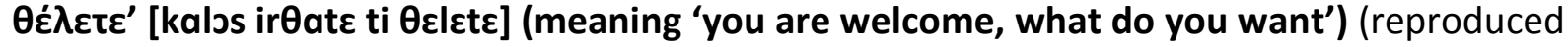
from Meyer (2015)). Here, the whistled form consists of the emulation of the quality of spoken vowels and consonants (formant-based whistling) (Listen also to corresponding audio files in Supplemental Material AudioFigure2a,b) 
a

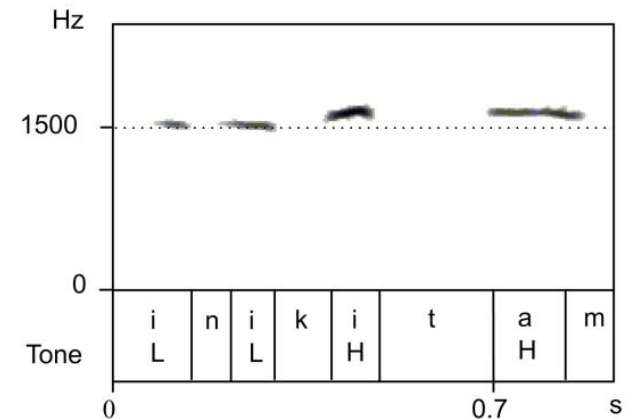

b

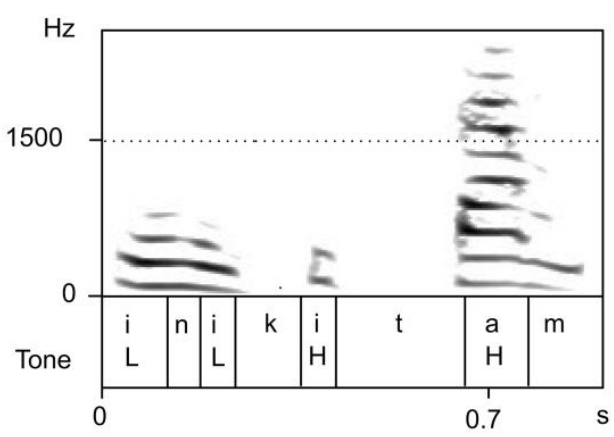

Figure 3: Spectrogram of the Gavião words 'ini kítấp' [ini kitam], meaning 'hammock rope', in whistled (a) and spoken (b) speech. (reproduced from Meyer (2015)). Here, the whistled form consists of the emulation of the pitch of the spoken modal form (pitch-based whistling) 